\title{
A genre analysis approach to the study of the translation of court documents
}

Anabel Borja Albi

Universitat Jaume I, Spain

borja@uji.es

This article describes an action research project on multilingual management and translation of court documents developed by the GENTT research group, which postulates that the notions of 'textual genre', 'genre system' and 'meta-genre' can be powerful tools for accessing and 'reusing' the linguistic and extra-linguistic information technical writers and translators need to manage specialised communication. To validate this hypothesis the criminal court genre systems of four countries (Germany, Spain, France and the United Kingdom) have been analysed and described from a legal-conceptual, discursive-textual and terminological perspective. The results of this contrastive analysis have been used as the basis for creating translation resources (both conceptual and linguistic), which have been organised into an online platform for translators of court documents. This platform is conceived as a knowledge system which will permit the 'reusability' of electronic translation resources. Our approach presents an integrative methodology for research into legal translation.

\section{Introduction}

This article, which falls within the fruitful line of research devoted to the analysis of legal discourse genres (e.g., Bhatia, 1987; Bhatia \& Evangelista, 2011; Chierichetti \& Garofalo, 2010; Harris, 1988; Orts Llopis, 2006) and its application to legal translation (Borja Albi, 2005, 2007; Engberg \& Wølch Rasmussen, 1999; Garofalo, 2009; Monzó, 2002), describes an action research project on multilingual management and translation of court documents developed by the GENTT group over the course of 2010 and $2011 .{ }^{1}$

With this project the GENTT group aims to contribute to a new line of theoretical speculation which postulates that the notions of textual genre, genre system and meta-genre can be very powerful tools to access and reuse the linguistic and extra-linguistic information technical writers and translators need to manage specialised communication. Following Ezpeleta Piorno (2012a, p. 139), the acquisition of competence in genre and genre systems can be considered an effective means of acquiring the 
abilities needed by linguistic mediators of professional texts, such as translators, since it facilitates their socialisation as communication agents in highly specialised domains.

The project is based on the hypothesis that the notions of textual genre, genre system and meta genre can help legal translators to understand how communicative acts are performed by the discursive community of legal professionals, and that translators can take advantage of this understanding to deal with the systemic anisomorphism, lexical mismatch and lack of terminological equivalence that make legal translation 'mission (almost) impossible'.

Legal discourse encompasses a large number of genres (wills, agreements, powers of attorney, statutes, law text books, law reports, legal opinions, etc.) which are organised into different subsets of interdependent genres and have interacting purposes and forms (Borja Albi, 2000). This study focuses on a particular set of legal texts, the subsystem of court documents used in criminal proceedings, a prime example of prefabricated discourse in institutional settings. Within this subsystem the exchange of information is initiated with an information laid before a court and concludes with a judicial decision made by the courts. An enormous number of documents (the bundle) is generated between these two points, following a strict technical and statutory procedure.

The participants in this institutional interaction constitute a welldefined discursive community, which includes judges, prosecutors, counsel for the defence, court clerks, police officers, witnesses, expert witnesses, defendants (and translators), among others. In this domain, the translator appears as an outsider from the discursive community with respect to both the source genres and the target genres, in the sense that he or she is not professionally engaged in drafting charge sheets, case summaries, statutory declarations or judgments.

Working from the premise that analysing and understanding the profound differences between legal systems is an essential prerequisite to be able to tackle the translation of legal documents and concepts with some assurance of success (Borja Albi, 2007; Engberg, 2012; Monzó, 2005; Šarčević, 1997, 2010; Wróblewski, 2000), the task here has been to compare the textual genre systems arising from the relationship between the public and the courts in four countries (Germany, Spain, France and the United Kingdom) from a legal-conceptual, discursive-textual and terminological perspective. The results of this contrastive analysis have been used as the basis for creating resources (both conceptual and linguistic), which have been organised into an online knowledge system (Borja Albi, 2005; Dam, Engberg, \& Gerzymisch-Arbogast, 2005) for translators of court documents.

The aim in doing so is to demonstrate that translators can become full members of this community, if they familiarise themselves with the 
source and target court documents genre system, one of the most technical and highly regulated of all.

\section{Textual genres, genre systems and meta-genres in institutional settings}

The framework of the research approach underlying this study is based on three theoretical concepts which shall be briefly defined: textual genre, genre system and meta-genre.

Linguistics and Translation Studies are heirs to the classical tradition of literary genres, and throughout history there have been repeated attempts to organise texts into types or categories in order to systematise their study and acquire a better understanding of their rhetorical and pragmatic mechanisms. Most recent theories of genre analysis, such as the systemic functional approach developed by Halliday (1978, 1985/1994) and extended by the Sydney school and the American school - both of which adopt a markedly sociological approach - have made decisive contributions to the field.

The Sydney school, with Halliday as its leading exponent, is well known for applying systemic-functional linguistics to the study of texts and by its contributions to the concept of register, which in linguistics is defined as a subset of a language used for specific purposes or in a restricted social domain. The American school, strongly influenced by the work of Burke and Searle and Austin on speech acts (the "New Rhetoric"), is notable, in turn, for diverting attention away from the structure and content of texts in favour of their contextual and sociological framework.

In Miller's view (1994), the use of the concept of genre as a recurring pattern of forms for classifying texts is reductionist, and she argues for a broader approach of a socio-cultural kind, locating genre in an intermediate position between the macro level of culture and the micro level of language. She defines genres as 'staged, goal-oriented social processes', which are realised through the register variables of field, tenor and mode. She argues that the study of genres should be directly related to the analysis of social structures (discourse communities), bringing her very close to the views of Swales (1990) and Bhatia (1993, 2004, 2011), who place individuals and their will to communicate at the origin of the concept of genre. Following Bhatia (1993), genres are instances of successful achievements of specific communicative purposes using conventionalized knowledge of linguistic and discourse resources.

Continuing in this line of work, we find applied studies devoted to language acquisition, especially $\mathrm{LSP}^{2}{ }^{2}$ and to translation practice and training. ${ }^{3}$ Bazerman (1994) proposes an instrumental approach applied to LSP; perhaps his main contribution is the concept of genre system 
(already postulated in Opacki, 1963/2000), regarding the existence of sets of interdependent genres. As Ezpeleta Piorno (2012a) points out:

Orlikowski and Yates' (2002) empirical work on the use of genres in organizational practice illustrated the fact that genres are linked to each other so as to constitute a structure that coordinates communicative actions, and thus they create expectations about the purpose, the content and form (including expectations about structuring devices and linguistic elements) of the whole system as well as those of its constituent genres. A genre system designates the participants involved, who typically initiates which genres, and to whom such genres are typically addressed. The different genres are also related by their relative timing and location, which may be physical or virtual, within the system. (p. 141)

Finally, the third concept we need in order to describe institutional genre systems, which include the court documents system, is that of metagenre. Bawarshi and Reiff (2010) locate the earliest definitions of this concept in the contributions of Giltrow:

Giltrow (2001:195) defines meta-genres as "atmospheres surrounding genres". Like genres, meta-genres have "semiotic ties to their contexts of use" (190), but their function is to provide shared background knowledge and guidance in how to produce and negotiate genres within systems and sets of genres. Meta-genres can take the form of guidelines or manuals for how to produce and use genres - genres about genres (190) - but they can also take the form of shared discourse about genres. (p. 94)

As Schryer and Spoel (2005) point out, meta-genres "help to elaborate the legal, ideological and power operations of genre systems, especially within institutional contexts, but also between institutions and companies or individuals" (pp. 256-257). They regulate and reinforce typicality in terms of the macro- and microstructure of other genres and provide a valuable way to understand the dynamics of institutional interrelations among genres (Ezpeleta Piorno, 2012b, p. 329).

GENTT proposes an eclectic concept of text genre, based on systemic functional linguistics, genre theory applied to translation and the sociology of professions (Borja Albi, 2005, 2007; García Izquierdo, 2005, 2009; Monzó, 2002). In our view, the translation studies approach that best represents the complexity of the phenomenon of translation is the socalled Textual Approach (e.g., Baker, 1992; Hatim \& Mason, 1990, Neubert \& Shreve, 1992). For GENTT genre is conceived as a notion that includes formal aspects (conventionalised forms), sociocultural aspects (social occasions) and cognitive aspects (purposes of the participants). 
These three dimensions are extremely important for understanding and translating the complexity of genres in different languages and cultures.

\section{Genre analysis and the notion of 'reusability'}

Since we understand the concept of genre as combining formal, communicative and cognitive features which provide important data for establishing the context of specialized documents, we propose that the notion of genre be used as a tool for accessing and reusing conceptual, textual and linguistic information and for managing specialised communication (Karjalainen, Päivärinta, Tyrväinen, \& Rajala, 2000; Tyrväinen \& Päivärinta, 1999).

The concept of reusability, derived from Computer Science, was adopted in Linguistics from the 1980s, when various European, American and Japanese research groups proposed projects and activities designed to reuse existing linguistic resources, with the aim of cutting costs. Reuse can be interpreted from two perspectives. On the one hand, it refers to reusing existing linguistic resources, even those that are not in digital form, which are used by Natural Language Processing (NLP) applications to develop new resources. On the other hand, it refers to constructing linguistic resources, whether by creating them or by using sources generated from other existing resources, which, in turn, can be reused in various applications and theoretical contexts and by various types of users (human and/or mechanical).

Given the proliferation of technologies applied to language, Information Science must update its practice, automate information management systems and streamline documentary tasks in close collaboration with the resources generated in Linguistics, to consolidate a practice that is both interdisciplinary and transdisciplinary (Moreiro González, 1994). The possibility of reusing linguistic resources is not only important for Linguistics, but also for other areas of knowledge, including Translation. In fact, the new demands of the information society led our group to think about designing an information management tool for highly specialised translators and explore how potential users (researchers and professional translators) could retrieve information more effectively. As a result, we had to enlist the services of experts in computing, computational linguistics and language processing to work on this new project.

Our team has begun to open up a new path of applied research which has involved, on the one hand, carrying out qualitative and quantitative studies on the habits and needs of professionals in the fields in question (legal translators in our case) and on the other, the implementation of computer tools to satisfy the needs identified. With new objectives, an enlarged team and a strategy revised for the purpose, we have continued working on theoretical issues related to genre and 
have tried to move forward in exploring its new potentialities, but, above all, to generate technology transfer. Our new action research project, described in section 5, therefore represents a step forward in a line of research consolidated by the GENTT team.

\section{The interaction of criminal court documents as a system of genres}

Law needs to be disseminated in order to become known, and, hence, from its origins it has had a strong textual component. Through writing, knowledge of Law is assured and it becomes possible to enforce it. Drafting, compiling, collecting and classifying legal texts have been activities connected with the legal world since time immemorial. Early examples that may be cited are the Code of Hammurabi (1700 BC), the Lex Duodecim Tabularum (462 BC) and the Codex Iustinianus (c. 530). Today, this classificatory effort can be seen in the online legal directories, databases and portals that provide online content and the retrieval tools to extract the required information from the massive amount available.

Being normative by nature, legal discourse tries to avoid ambiguity by using the same expressions and structures that have already been construed in a certain way by judges. Throughout history, lawyers have been generating highly stereotyped and repetitive documents which constitute perfectly well-defined textual genres, legal genres. This feature, which is not found in other areas of knowledge such as Medicine or Economics, for example, where much freer and more open textual forms are used, greatly facilitates its discursive analysis and systematisation.

The criminal court documents genre system can be regarded as a subsystem of legal discourse, and its components are even more prescriptive, stereotyped and systemic than other legal genres such as legal doctrine, statutes or contracts, for example. It undoubtedly constitutes a prototypical example of what some scholars ${ }^{4}$ define as a genre system: interdependent genres which appear as certain typical sequences and which form relations with one another and have interacting purposes and forms.

Indeed, the court documents system consists of a set of genres which function as part of an interlocking mechanism with a perfectly well-defined order of appearance (claim, defence, court order, judgment), interrelationship (claim/counterclaim, judgment/appeal, defence opening statement/prosecution opening statement, and so on) and complementarity, to achieve a very specific communicative purpose: to give remedy to a claim lodged before the courts.

Another feature which confirms the systemic nature of judicial documents is their dependence on a meta-genre: each country's laws on criminal or penal procedure. These are statutory instruments (France: Code de procédure pénale française; Germany: Strafprozeßordnung; 
Spain: Ley de Enjuiciamiento Criminal; United Kingdom: Criminal Procedure Act 2005 and the arch-authority Archbold ${ }^{5}$ ), which regulate the course of proceedings, the time and order of appearance of participants and documents, the deadlines and appointed places for submitting documents, their communicative sequences and interrelationship, as well as their format, execution formalities, and even their content and macrostructure.

Let us look at an example of this assertion in the English Criminal Procedure Rules 2005 on how to tender a witness statement before a magistrates' court. Note that this section refers the reader to another legal document (the Practice Direction) for matters of form:

27.1.-(1) Written statements to be tendered in evidence in accordance with section 5B of the Magistrates' Courts Act 1980(1) or section 9 of the Criminal Justice Act 1967(2) shall be in the form set out in the Practice Direction.

Another example, this time from section 266 of the Spanish Ley de Enjuiciamiento Criminal (Criminal Procedure Act), provides a prescriptive definition of how to present a written complaint (denuncia in Spanish):

Artículo 266.

La denuncia que se hiciere por escrito deberá estar firmada por el denunciador; y si no pudiere hacerlo, por otra persona a su ruego. La autoridad o funcionario que la recibiere rubricará y sellará todas las hojas a presencia del que la presentare, quien podrá también rubricarla por sí o por medio de otra persona a su ruego.

Intertextuality is another element which reinforces the systemic nature of this communicative interaction. In this particular domain it is achieved by means of two mechanisms:

- $\quad$ references to points of law and procedural requirements (usually from Penal Codes and Rules of Procedure), and

- $\quad$ references to previous interactions, court hearings and documents in the case bundle which mark the procedural iter of the case.

We can therefore identify a first level of intertextuality in the constant references to criminal codes and case law, with the former predominating in civil law countries and the latter in common law countries. At this level, we also find references to other statutory documents such as civil law statutes, the constitution or lower-order norms and regulations.

The second level of intertextual references mentioned above is a unique feature of this genre system and functions as a milestone model. Such references serve to mark the procedural iter of the case, the case 
identifying details, the various courts where it has been heard, and the immediately preceding document which has generated the next one in the sequence. We find them at the beginning of every document (name of court, case number, identification of parties) and in the factual description of the case and the judicial iter it has gone through, that is, the court where it started in first instance and the appeal courts (if any) in which it has been heard on appeal, or references to documents in the bundle previously served or otherwise used.

Court bundles are usually required for any case that appears in court. The idea is that the judge will be able to pre-read all the relevant documents in the case. All the parties will also have all the evidence and copies of any precedents collected together in one place, making it easier to refer to information during the trial.

Some important documents in the bundle are: (a) preliminary documents and any case management documents; (b) applications and orders; (c) statements and affidavits (which must be dated in the top rightcorner of the front page); (d) experts' reports and other reports; and (e) any other documents, divided into further sections as appropriate. In addition to these documents, some courts require up-to-date summaries of matters relevant to the hearing; statements of issues to be determined; position statements from each party, including a summary of orders sought; a chronology; skeleton arguments; and lists of essential reading.

Another distinctive feature of a system of genres is the possibility of identifying a closed discursive community which makes use of them. In this respect, judicial genres are a clear reflection of the discursive practices of a community of professionals: "“...] every professional genre, at least for the members of the professional community and other experts, has an identity of its own, which is a kind of 'trademark' for the profession it is typically used in" (Bhatia, 2011, p. 33).

\section{The JudGENTT action research project}

Working on the basis of the theoretical approaches set out in previous sections of this article, GENTT has developed an action research project aimed at improving the working processes of court translators by designing an intelligent multilingual legal documentation management system that makes it possible to automate processes of retrieval, indexing, semi-controlled composition and assisted translation of texts generated in judicial environments, always taking account of the needs, habits and processes of the end users of the texts, in this case legal translators, and in particular, criminal court translators.

This government-funded project is a good example of applied research and cooperation between the university and the Judiciary, a public body of great social relevance. We describe it as an action research 
initiative, as our motto is 'no action without research and no research without action'. following:

The research stages we have defined for our project are the

1. Needs analysis

2. Genre system analysis (France, Germany, Spain and England and Wales)

a. Mapping of field documents (identification of the criminal court documents used in each country)

b. Individual genre analysis (drafting of genre matrices and templates for the genres identified)

c. Court documents corpus compilation and exploitation

d. Gathering of conceptual/contextual information.

3. Management tool design and implementation

From a methodological point of view, we have used a mixed approach: qualitative because we carry out the needs analysis by means of personal interviews and surveys, and quantitative, because in the last stages we have relied on corpus analysis methods and statistical calculations.

\subsection{Needs analysis}

In the needs analysis phase of the project we conducted a survey among court translators and interviewed both translators and court agents responsible for translation services. As a result, we detected serious deficiencies in translators' document management processes. Despite the fact that this is a field in which repetitive and stereotyped models of texts are used, a total lack of systematisation was observed in document management procedures. It was noted that, in most cases, court translators:

- $\quad$ use computer equipment which is obsolete and ineffective;

- do not use and are not aware of translation software (translation memories, multilingual management databases, alignment tools, indexing tools...);

- do not have databases of models or templates approved by the whole socio-professional community, either for monolingual drafting or for translation;

- do not have access to intelligent interfaces enabling them to retrieve documents, terminology, phraseology or translations quickly and effectively using different search parameters; 
- do not reuse linguistic or translation resources effectively or do not use them at all.

In an ideal situation, translators and interpreters in such a specialised field should be working with all the resources necessary to conduct their working activity in optimum conditions. However, it seems this is far from being the reality, at least in Spanish courts.

\subsection{Genre system analysis}

Following Bhatia, to describe and understand a system of genres one needs a framework which makes use of both the discourse-based textinternal internal evidence and the discipline- and profession-based understanding of text-external resources (Bhatia, 2011, p. 33).

\subsubsection{Mapping of field documents (identification of the criminal court documents used in each country)}

The first step to obtain discourse-based evidence is the identification and description of the catalogue of genres that make up the system (textual mapping of the field). The fact that the law of procedure describes and establishes the documents that must be used in criminal proceedings, and that lawyers have a habit of using forms and precedents, enormously facilitates the identification of criminal court genres. In establishing the catalogues of criminal court genres for Spain, France, Germany and the United Kingdom this project has benefited from the help of lawyers who are experts in procedural law: liaison magistrates, judges, court clerks, and senior court translators.

As was to be expected, there are substantial differences between these catalogues, since the system of genres depends on the procedural technique of each country, though the greatest differences are to be found between the catalogue of UK documents and the ones for Continental law countries, owing to the fact that in the UK a major part of the interaction is oral. This fact has important implications for translation, since we face problems of anisomorphism in the actual nomenclature, content and function of the documents that make up the system. The list of criminal court documents identified for the UK criminal process can be seen in the following figure. 


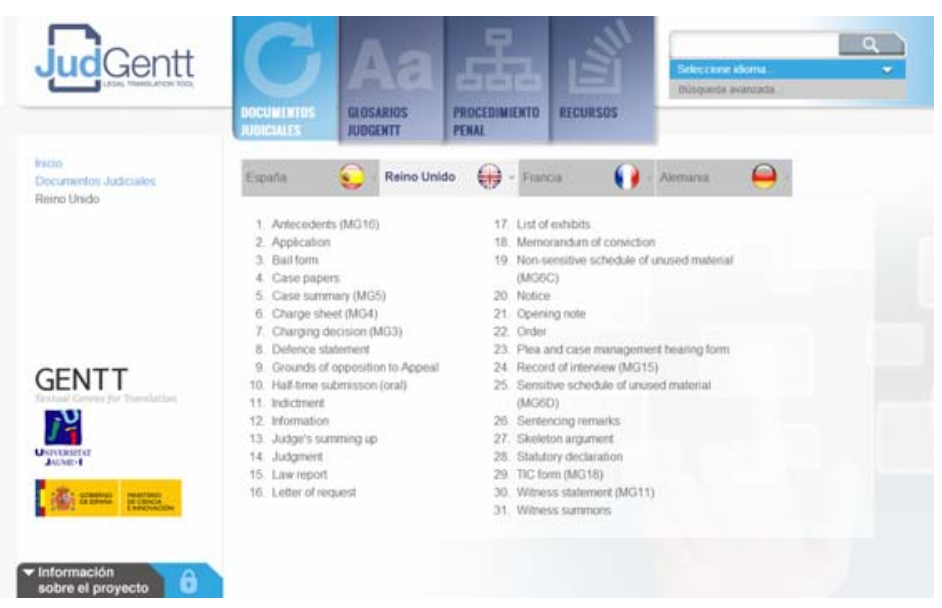

Figure 1: Catalogue of criminal court documents UK

5.2.2 Individual genre analysis (drafting of genre matrices and templates for the genres identified)

In our project, as well as identifying the documents of the criminal court genre system in four countries, an explanatory genre matrix has been created for each genre. By clicking on "Indictment", for instance, a window opens showing its genre matrix. 
Table 1: JudGENTT genre matrix.

\begin{tabular}{|c|c|}
\hline Genre & Indictment \\
\hline Other names & Bill of indictment \\
\hline Definition & $\begin{array}{l}\text { A written statement of the details of the crime with which } \\
\text { someone is charged in the Crown Court. Source: CoLLIN, P. } \\
\text { (2004): Dictionary of Law, London, Bloomsbury Publishing. } \\
\text { A written accusation of a crime against one or more persons - a } \\
\text { criminal trial in the Crown Court cannot start without a valid } \\
\text { indictment; Source: http://www.justice.gov.uk/courts/procedure- } \\
\text { rules/criminal/docs/Glossary-2013.pdf } \\
\text { In the Crown Court the defendant is 'tried on the indictment'. It } \\
\text { is a document which details the charges, and particularises the } \\
\text { offence. It is drafted by the prosecutor and 'lodged' with the } \\
\text { Crown Court (the term for official service on the court of the } \\
\text { indictment). Source: Marc Robinson. Liaison Magistrate UK- } \\
\text { Spain. Spanish Ministry of Justice. } \\
\text { Documento inculpatorio, acta o escrito de acusación solemne } \\
\text { utilizado en los juicios con jurado presididos por jueces } \\
\text { profesionales en el Crown Court; cumple la misma función que } \\
\text { la information en los juicios celebrados en el Magistrate's } \\
\text { Court. Source: AlcARAZ, E y B. HuGHES (1995): Diccionario } \\
\text { de términos jurídicos inglés-español/español-inglés, Ariel, } \\
\text { Barcelona }\end{array}$ \\
\hline $\begin{array}{l}\text { Communicative } \\
\text { situation }\end{array}$ & $\begin{array}{l}\text { Sender: Prosecutor } \\
\text { Receiver: Court } \\
\text { Contextualization in the judicial iter: Preliminary proceedings }\end{array}$ \\
\hline Subgenre & \\
\hline $\begin{array}{l}\text { Equivalent } \\
\text { genre } \\
\text { (in other } \\
\text { languages) }\end{array}$ & $\begin{array}{l}\text { Spain: acta o escrito de acusación, documento inculpatorio } \\
\text { France: Requisitoire } \\
\text { Germany: Anklageschrift }\end{array}$ \\
\hline Legal framework & $\begin{array}{l}\text { The Crown Prosecution Rules } 2010 \text { (Part 14, The indictment) } \\
\text { http://www.justice.gov.uk/courts/procedure-rules/criminal/docs/crim-proc-rules- } \\
\text { 2012-part-14.pdf } \\
\text { Archbold (1-192) } \\
\text { Indictments Act } 1915 \text { (The Indictment Rules } 1971 \text { have been } \\
\text { revoked and (by and large) incorporated into CPR 2010). }\end{array}$ \\
\hline Macrostructure & 14.2.- \\
\hline
\end{tabular}




\begin{tabular}{|c|c|}
\hline & 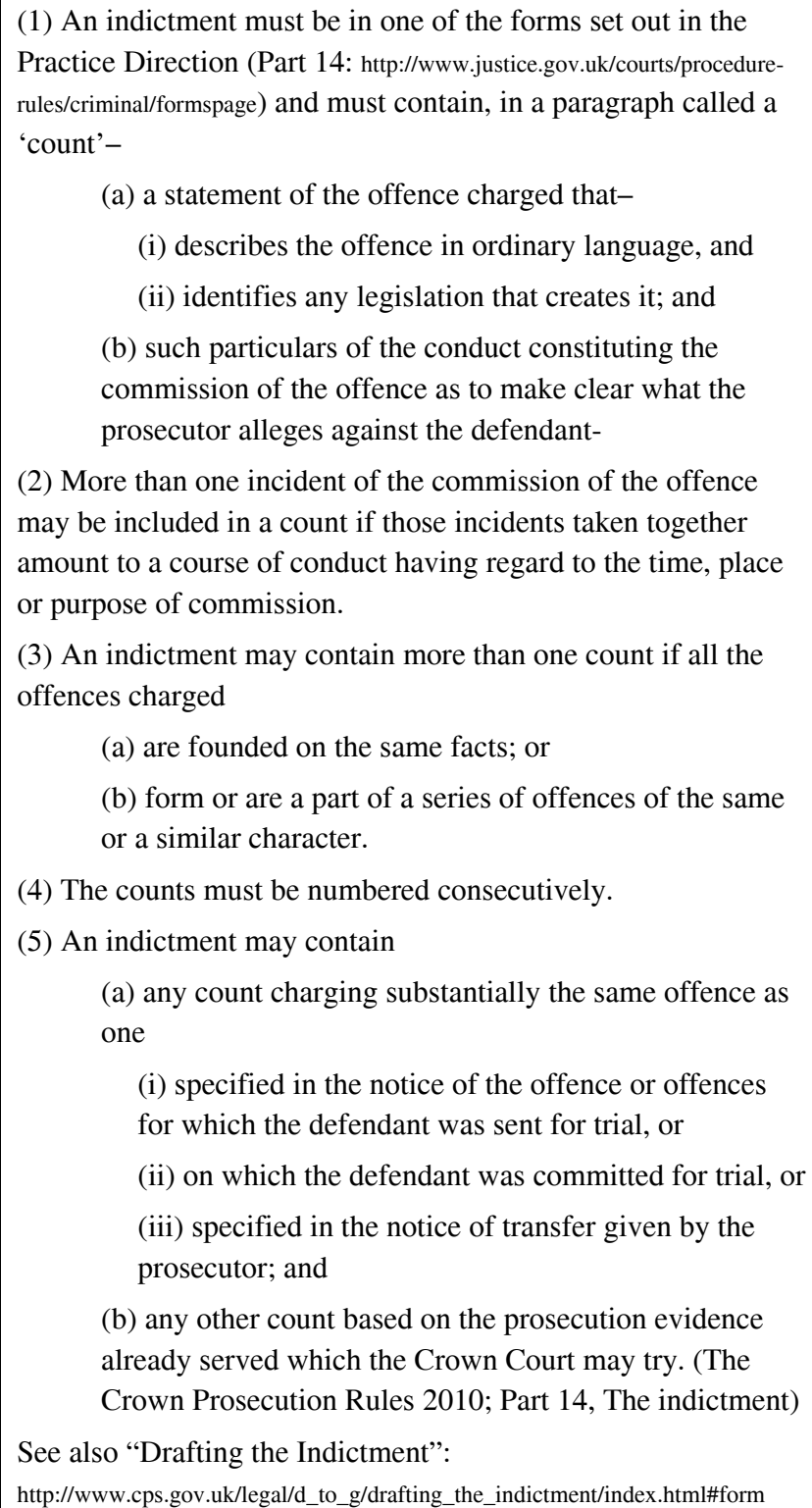 \\
\hline $\begin{array}{l}\text { Documents in } \\
\text { JudGENTT corpus }\end{array}$ & $\begin{array}{l}\text { 4040_OR_EN } \\
\text { 4042_OR_EN } \\
\text { 3067_TR_EN_ES }\end{array}$ \\
\hline
\end{tabular}

A good knowledge of the taxonomy of legal texts enables the translator to achieve an overall grasp of the discipline and a clear view of its internal structure. Moreover, knowledge of textual typology is essential for structuring the process of making decisions on procedures and strategies 
in legal translation, which differ from one category of texts to another, and sometimes within each particular genre. A comparison of the genre matrices of the four countries studied offers comparative elements which are extremely useful to legal translators.

\subsubsection{Court documents corpus compilation and exploitation}

As well as the catalogue and the genre matrix for each genre identified, we also felt that the translator needs to be able to access some textual models of each. Thus, we have collected several forms and authentic documents for each of the genres identified which are part of the JudGENTT corpus and can be accessed from the last section of the genre matrix or through the search engine (see Figure 1: top right corner). Becoming familiar with the various different court genres fosters the translator's textual competence, in the sense of enhancing his or her mimetic skill and ability to adapt to the style, tone, etc.

To compile monolingual corpora for the four systems studied, we have resorted to domestic institutional websites, such as the German, French and Spanish Ministries of Justice, or the Courts Service in England and Wales, where we can find and download the statutory instruments on criminal court procedure (and criminal law), explanatory literature on criminal procedure and an unlimited number of judgments, as well as all kinds of court forms and precedents. Another important source of materials for the monolingual corpora has been fellow translators, lawyers and judges.

The possibilities that computing offers nowadays to compile electronic corpora of a genre or a specific system of genres are unlimited. However, compiling bilingual corpora of translated criminal court documents has been far from easy. We have found resources on the sites mentioned above, which offer part of their legislation and rules of procedure translated into other languages, and especially on the websites of organisations concerned with matters of international criminal justice, such as the International Criminal Court or Interpol. We contacted court translators asking them to collaborate in the project with their own translations by signing a confidentiality agreement and removing, of course, all personal details. Some contributions have been obtained in this manner, but unfortunately not as many as we would have expected.

The second step we took to obtain discourse-based evidence was to apply corpus analysis techniques to extract specialised monolingual and bilingual terminological and phraseological glossaries from the ad-hoc corpora we have compiled. We have used alignment and terminology extraction tools such as Synchroterm, which automatically extract specialised terms and create terminology and phraseology records from source and target document pairs, bitexts and translation memories. Context of use was recorded for each term or phrase. Legal definitions 
were added by the research team to the terminological records in Excel format to obtain monolingual glossaries. We are presently revising the final products with the help of legal experts and linguists.

\subsubsection{Gathering of conceptual/contextual information}

Having established the existence of a well-defined taxonomy of texts (which form the object of this branch of translation) we cannot overlook the fact that court discourse relies on a complex conceptual system (which forms the field of discourse). Translators without legal knowledge are, in principle, unaware of this discourse but they must master it in order to satisfy the expectations of their users, their discursive community.

For the purposes of this research project we have taken the view that the discipline and profession-based understanding of text-external resources should include the following elements:

- $\quad$ Courts hierarchy

- $\quad$ Legislation on criminal law and procedure (system meta-genre)

- $\quad$ Participants in the criminal process

- $\quad$ Outline summaries of the judicial processes and their phases

- Classification of criminal offences and penalties.

Law is not a universal discourse. Each country has a distinct legal system with a unique identity developed over centuries. The divergent roles of legal actors, court structures, procedural aspects, and classification of criminal offences and penalties in each country's legal system constitute a paradigmatic example of system-bound terminology which the translator cannot tackle without a quite profound knowledge of comparative law. Legal translation is a complex interplay of cultural values, concepts and principles, and in a sense legal translators are engaged in the comparative law quest for a legal meta-language.

Our study has identified important differences between countries in all four sections. If, for instance, we turn our attention to the second element, the range of participants involved in the process (judges, prosecutors, counsel for the defence, court clerks, police officers, witnesses, expert witnesses, defendants and translators) we find that their functions, qualifications, scope of involvement and responsibility are highly dissimilar. 


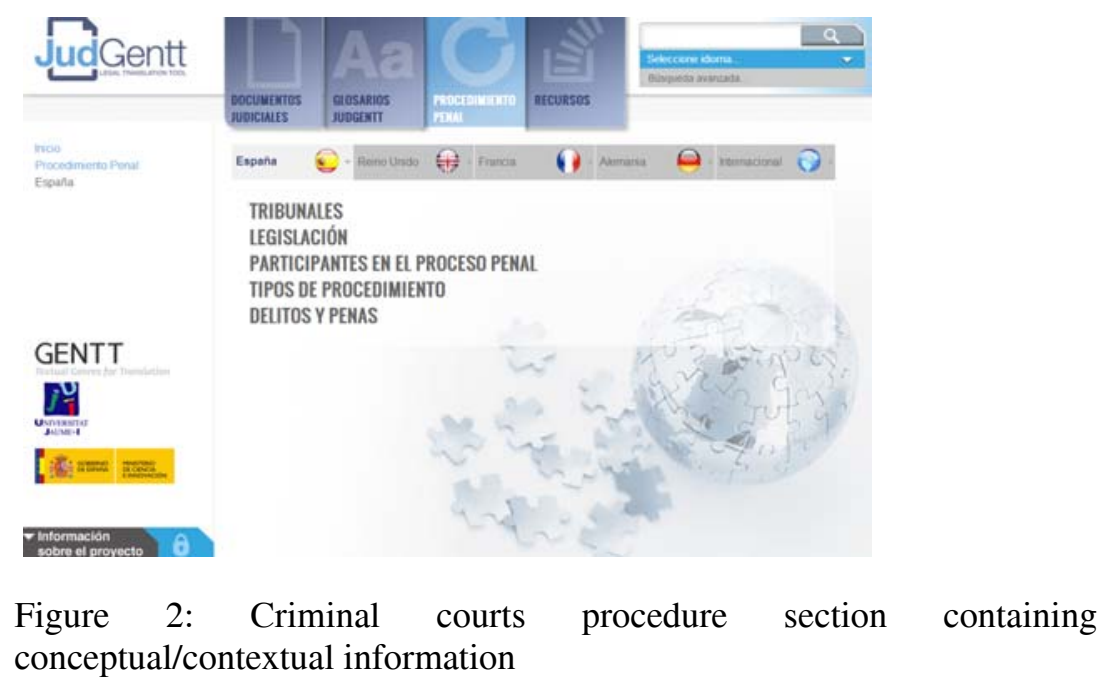

5.3 Management tool design and implementation. The JudGENTT platform of resources for translators of court documents

The results of the project have been incorporated into the JudGENTT platform $^{6}$ in which professional legal translators, associations, public institutions and companies have collaborated. It offers legal translators a range of linguistic and legal resources which facilitate the conceptual and terminological documentation process, making the comparative analysis of legal terms and concepts easier, and helping them to reuse existing translations more effectively. In its current phase it includes resources related to four legal systems: Germany, Spain, France and the United Kingdom. The contents collected or compiled so far are organised in five sections:

- A Catalogue of criminal court documents which includes a list of the documents used in criminal judicial procedure in the four domestic legal systems studied (see Figure 1), accompanied by an explanatory genre matrix on each of them (see Table 1).

- A section called Criminal courts procedure, in which conceptual/contextual information pertaining to the four national systems can be found (see Section 5.2.4 and Figure 2).

- A series of specialized Glossaries of judicial terminology and phraseology created by extracting terminology from the platform's corpus of texts. There are monolingual (English, French, German and Spanish) and bilingual glossaries (Spanish-English, SpanishFrench and Spanish-German). All entries are accompanied by a definition (in monolingual glossaries), a proposal of equivalence 
into another language (in bilingual glossaries) and the context from which they have been extracted.

- A Resources for translators section, which includes a subsection for Bibliography and another for Links, with connections to useful web pages and portals for legal translators.

- However, the most important contribution this tool offers is the adhoc corpus of criminal court documents the team has compiled. It is made up of monolingual corpora in four languages (Spanish, English, French and German) and bilingual corpora (in the different combinations of Spanish and the other three languages). It comprises genuine judicial documents (originals and translations) from which personal details have been removed, and forms or precedents. This corpus is the database for the tool's integrated search facility, which covers all sections of the site and retrieves results of various types depending on the search criteria selected in the advanced search window.

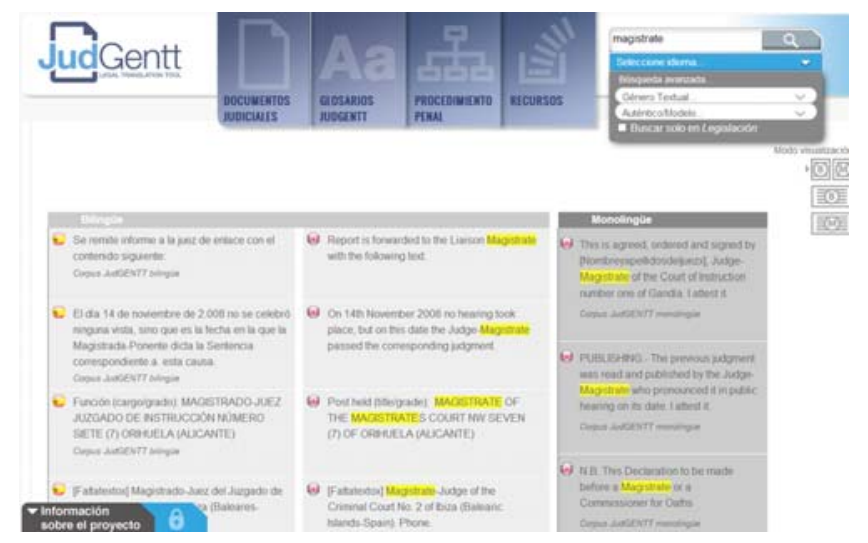

Figure 3: Search engine results page

\section{Conclusion}

In this article we have presented the results of an action research project on legal translation: the JudGENTT platform of resources for criminal courts translators. It has been developed using an integrative methodology for research into legal translation that applies different perspectives and makes it possible to combine the theoretical frameworks and methodological procedures used in each of the related sciences involved in professional legal translation: Law, Linguistics, Translation Studies and Information Technology.

By describing the JudGENTT platform we have provided an example of how such an integrative approach can be applied to the study 
of a particular system of legal genres in four different countries and how the results of this study can improve the socio-professional conditions of legal translators and their production processes. A strategy is proposed for improving the processes and products of translators' work by introducing new technologies that can be incorporated into their daily routines and encourage networking. To achieve this, we have built an electronic tool (JudGENTT platform) specially designed to meet the needs of translators identified in the needs analysis phase of the study.

Our team is now piloting the implementation of the platform in several Spanish courts and we hope to have conclusive results on its effectiveness and acceptance by its intended users very soon.

Further developments include the application of this platform to other fields of specialised translation. This possibility has already been explored with the development of a similar platform for legal medical documents (living wills, informed consents, medical insurance policies, etc.) which is now being finalized and will soon enter the testing phase.

The possibility of automating multilingual specialised communication in institutions and large companies which use documents in several languages is one of the greatest challenges that linguistics and translation currently face, as is demonstrated by the initiatives already implemented successfully in international organisations (EURAMIS in the European Union; ENGSPAM and SPANAM in the Pan American Health Organization) and in multinational companies (Microsoft Language Portal, Microsoft Terminology corpus; Novell eTerm; Sun Microsystems). These organisations have high-powered groups of linguists, terminologists and translators who have instigated initiatives of this kind.

However, the institutions for which our proposal is intended (courts, hospitals, small and medium-sized enterprises), despite their high volume of conventionalised text composition and repetitive translation, lack the resources to implement electronic tools that can contribute to improving their processes and products. We hope that the management tool we have designed and which we are now evaluating in a professional domain of great social relevance (courts) may contribute to modernising their administrative processes and consequently enhancing the services provided to the public in so sensitive a field as justice.

\section{References}

Baker, M. (1992). In other words. London: Routledge.

Bawarshi, A. S., \& Reiff, M. J. (2010). Genre: An introduction to history, theory, research, and pedagogy. West Lafayette, IN: Parlor.

Bazerman, C. (1994). Systems of genres and the enactment of social intentions. In A. Freedman \& P. Medway (Eds.), Genre and the new rhetoric (pp. 79-101). London: Taylor \& Francis. 
Bhatia, V. K. (1987). Textual-mapping in British legislative writing. World Englishes 6(1), 1-10.

Bhatia, V. K. (1993). Analysing genre: Language use in professional settings. London: Longman.

Bhatia, V. K. (2004). Worlds of written discourse: A genre-based view. London: Continuum.

Bhatia, V. K. (2011). Contested identities in corporate disclosure documents. In V. K. Bhatia \& P. Evangelisti Alloria (Eds.), Discourse and identity in the professions: Legal, corporate and institutional citizenship (pp. 27-44). Bern: Peter Lang.

Bhatia V. K., \& Evangelista Allori, P. (Eds.). (2011). Discourse and identity in the professions: Legal, corporate and institutional citizenship. Bern: Peter Lang

Borja Albi, A. (2000). El texto jurídico inglés y su traducción al español. Barcelona: Ariel.

Borja Albi, A. (2005). Organización del conocimiento para la traducción jurídica a través de sistemas expertos basados en el concepto de género textual. In I. García Izquierdo (Ed.), El género textual y la traducción: Reflexiones teóricas y aplicaciones pedagógicas (pp. 37-68). Bern: Peter Lang.

Borja Albi, A. (2007). Los géneros jurídicos. In E. Alcaraz \& J. Yuste (Eds.), Las lenguas profesionales y académicas (pp. 141-153). Barcelona: Ariel.

Chierichetti, L., \& Garofalo, G. (Eds.) (2010). Lengua y derecho: Lineas de investigación interdisciplinaria. Bern: Peter Lang.

Dam, H. V., Engberg, J., \& Gerzymisch-Arbogast, H. (Eds.). (2005). Knowledge systems and translation. Berlin: Mouton de Gruyter.

Engberg, J. (2012). Comparative law for translation: The key for successful mediation between legal systems. In A. Borja Albi \& F. Prieto Ramos (Eds.), Legal translation in context: Professional issues and prospects (pp. 9-26). Bern: Peter Lang.

Engberg, J., \& Wølch Rasmussen, K. (1999). Genre analysis of legal discourse. Hermes Journal of Linguistics, 22, 113-132.

Ezpeleta Piorno, P. (2012a). An example of genre shift in the medicinal product information genre system. In V. Montalt-Resurrecció \& M. Shuttleworth (Eds.), Linguistica Antverpiensia New Series - Themes in Translation Studies 11: Translation and knowledge mediation in medical and health settings (pp. 139-159). Antwerp: Antwerp University Press.

Ezpeleta Piorno, P. (2012b). Meta-genres and medicinal product information. Panacea, 13(36), 327-332.

Ezpeleta Piorno, P., \& Gamero Pérez, S. (2004). Los géneros técnicos y la investigación basada en corpus: Proyecto GENTT. In R. Gaser, C, Guirado, \& J. Rey (Eds.), Insights into scientific and technical translation (pp. 147156). Barcelona: PPU.

García Izquierdo, I. (Ed.). (2005). El género textual y la traducción: Reflexiones teóricas y aplicaciones pedagógicas. Bern: Peter Lang.

García Izquierdo, I. (2009). Divulgación médica y traducción. El género: Información para pacientes. Bern: Peter Lang. 
Garofalo, G. (2009). Géneros discursivos de la justicia penal: Un análisis contrastivo italiano-español orientado a la traducción. Milan: Franco Angeli.

Giltrow, J. (2001). Meta-genre. In R. M. Coe, L. Lingard, \& T. Teslenko (Eds.), The rhetoric and ideology of genre: Strategies for stability and change (pp. 187206). Cresskill, NJ: Hampton.

Halliday, M. A. K. (1978). Language as a social semiotic: The social interpretation of language and meaning. London: Edward Arnold.

Halliday, M. A. K. (1985/1994). An introduction to functional grammar. London: Arnold.

Harris, S. (1988). Court discourse as genre. In R. P. Fawcett \& D. J. Young (Eds.), New developments in systemic linguistics, Vol. 2: Theory and application. London: A\&M.

Hatim, B., \& Mason, I. (1990). Discourse and the translator. London: Longman.

Karjalainen, A., Päivärinta, T., Tyrväinen, P., \& Rajala, J. (2000). Genre-based metadata for enterprise document management. In R. H. Sprague (Ed.), Proceedings of the $33^{\text {rd }}$ Annual Hawaii International Conference on System Sciences. Los Alamos, CA: IEEE Computer Society Press, CD-ROM.

Miller, C. R. (1994). Rhetorical community: The cultural basis of genre. In A. Freedman \& P. Medway (Eds.), Genre and the new rhetoric (pp. 67-78). London: Taylor \& Francis.

Monzó, E. (2002). La traducción jurídica a través de los géneros de especialidad: El transgénero y la socialización del traductor en los procesos de enseñanza/aprendizaje. Discursos. Estudos de Traduçao 2, 21-36.

Monzó, E. (2005). Cómo traducir derecho sin ser jurista: Nuevas fuentes y medios documentales para la traducción jurídica. In A. Sales (Ed.), La biblioteca de Babel: Documentarse para traducir (pp. 123-146.). Granada: Comares.

Moreiro González, J. A. (1994). Documentación y lingüística: Conceptos de relación esenciales. Ciencias de la Información 25(4), 202-211.

Neubert, A., \& Shreve, G. M. (1992). Translation as text. Kent, OH: The Kent State University Press.

Opacki, I. (1963/2000). Royal genres. In D. Duff (Ed.), Modern genre theory (pp. 118-126). London: Longman.

Orlikovski, W., \& Yates, J. (2002). Genre systems: Structuring interaction through communicative norms. Journal of Business Communication 39(1), 13-35.

Orts Llopis, M. A. (2006). Aproximación al discurso jurídico en inglés en las pólizas de seguro marítimo de Lloyd's. Madrid: Edisofer.

Richardson, J. (Ed.). (2012). Archbold: Criminal pleading, evidence and practice (61st ed.). London: Sweet \& Maxwell.

Šarčević, S. (1997), New approach to legal translation. London: Kluwer Law International.

Šarčević, S. (2010). Creating a pan-European legal language. In M. Gotti \& C. Williams (Eds.), Legal discourse across languages and cultures (pp. 23-50). Bern: Peter Lang.

Schryer, C. F., \& Spoel, P. (2005). Genre theory, health care discourse, and professional identity formation. Journal of Business and Technical Communication 19(3), 249-278. 
Spain. Ley de Enjuiciamiento Criminal. Real decreto de 14 de septiembre de 1882 por el que se aprueba la Ley de Enjuiciamiento Criminal. Boletín Oficial del Estado, núm. 260, de 17/09/1882.

Spinuzzi, C. (2003). Tracing genres through organizations: A sociocultural approach to information design. Cambridge, MA: MIT Press.

Swales, J. (1990). Genre analysis: English in academic and research settings. Cambridge: Cambridge University Press.

Tyrväinen, P., \& Päivärinta, T. (1999). On rethinking organizational document genres for electronic document management. In R. H. Sprague (Ed.), Proceedings of the $32^{\text {nd }}$ Annual Hawaii International Conference on System Sciences. Los Alamitos, CA: IEEE Computer Society Press, CD-ROM.

United Kingdom. The Criminal Procedure Rules 2005. No. 384 (L. 4). Retrieved 13, March 2013, from http://www.legislation.gov.uk/uksi/2005/384/contents/made

Wróblewski, J. (2000). Il problema della traduzione giuridica. Ars Interpretandi. Annuario di ermeneutica giuridica. Traduzione e diritto 5, 155-164.

1 This article is part of the research project: 2010-2012 (FFI2009-08531/FILO), funded by the Spanish Ministry of Science and Innovation (MICINN) and developed by the GENTT research group of the University Jaume I (Spain).

2 A critical account of the most significant contributions in this line of theoretical thought can be found in Bawarshi and Reiff (2010.

3 See www.gentt.uji.es.

4 Bazerman, 1994; Ezpeleta, 2012b; Ezpeleta Piorno \& Gamero Pérez, 2004; Spinuzzi, 2003.

5 Archbold Criminal Pleading, Evidence and Practice (usually referred to simply as Archbold) is the leading practitioners' text for criminal lawyers in England and Wales and several other common law jurisdictions around the world.

6 The JudGENTT web page has been developed with Drupal as a platform (database, corpus, $\mathrm{html}$ resources, etc.) and uses a Lucene and Solr text search engine library. 